\title{
Yield and leaf concentrations of nutrients of melon crop and fertility of soil fertigated with $\mathrm{N}$ and $\mathrm{K}$
}

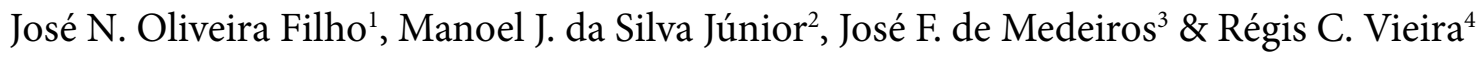 \\ ${ }^{1}$ Universidade Federal do Ceará/Departamento de Engenharia Agrícola. Fortaleza, CE, Brasil. E-mail: nilsonoliveira.f1@gmail.com (Corresponding author) - \\ ORCID: 0000-0001-8580-8727 \\ ${ }^{2}$ Universidade Federal Rural do Semi-Árido/Departamento de Engenharia e Ciências Ambientais. Mossoró, RN, Brasil. E-mail: mjanuario@ufersa.edu.br - \\ ORCID: 0000-0003-4419-7661 \\ ${ }^{3}$ Universidade Federal Rural do Semi-Árido/Departamento de Ciências Agronômicas e Florestal. Mossoró, RN, Brasil. E-mail: jfmedeir@ufersa.edu.br - ORCID: \\ 0000-0003-1202-8783 \\ ${ }^{4}$ Universidade Federal Rural do Semi-Árido/Departamento de Fitotecnia. Mossoró, RN, Brasil. E-mail: vieiraregisc@hotmail.com - ORCID: 0000-0002-4180-8474
}

\begin{abstract}
The use of fertigation as a means of supplying the nutritional needs of crops is a technique widely used among producers. However, it is necessary to improve this technique due, mainly, to the risks of contamination of natural resources. Thus, the objective was to study the productivity and leaf contents of melon nutrients and soil fertility, which presents a high concentration of potassium, when fertigated with doses of nitrogen and potassium in the irrigation water. Five treatments were arranged in randomized blocks with six repetitions. Treatments consisted of combinations of concentrations, in $\mathrm{mg} \mathrm{L}^{-1}$, of nitrogen $(\mathrm{N})$ and potassium (K) applied in irrigation water (0-0), (50-0), (50-54), (0-54) and (100-108). The leaf concentrations of nutrients of melon were evaluated at 35 days after planting, and fruit yield and soil fertility at harvest time. The melon cultivated in soil with a high level of $\mathrm{K}$ and basal application of $18 \mathrm{~kg} \mathrm{ha}^{-1}$ of $\mathrm{N}$ in the foundation did not increase production, when fertirrigated with nitrogen and potassium. Although the contents of $\mathrm{K}, \mathrm{Fe}$ and $\mathrm{B}$ varied between the doses of $\mathrm{N}$ and $\mathrm{K}$ applied, the plants did not have nutritional deficiency. Fertilizer applications in increasing doses contribute to the accumulation of salts in the soil, increasing the risk of salinization.
\end{abstract}

Key words: Cucumis melo L., melon Cantaloupe, salinity

\section{Produtividade e teores foliares de nutrientes do meloeiro e fertilidade do solo fertigado com $\mathrm{N}$ e $\mathrm{K}$}

RESUMO: O uso da fertigação como meio de suprimento das necessidades nutritivas das culturas é uma técnica amplamente difundida entre os produtores. Contudo, a necessidade de aprimoramento desta técnica se faz necessário devido, principalmente, aos riscos de contaminação dos recursos naturais. Assim, objetivouse estudar a produtividade e os teores foliares de nutrientes do meloeiro e fertilidade do solo que apresenta alta concentração de potássio, quando fertigado com doses de nitrogênio e potássio na água de irrigação. Aplicaram-se cinco tratamentos dispostos em blocos casualizados com seis repetições. Os tratamentos consistiram nas combinações de concentrações, em $\mathrm{mg} \mathrm{L}^{-1}$, de nitrogênio $(\mathrm{N})$ e potássio $(\mathrm{K})$ aplicadas na água de irrigação (0-0), (50-0), (50-54), (0-54) e (100-108). Foram avaliados os teores foliares de nutrientes do meloeiro aos 35 dias após o plantio, e a produtividade e a fertilidade do solo por ocasião da colheita. $\mathrm{O}$ meloeiro cultivado em solo com nível alto de $\mathrm{K}$ e aplicação de $18 \mathrm{~kg} \mathrm{ha}^{-1} \mathrm{de} \mathrm{N}$ em fundação não aumentou a produção quando fertirrigado com nitrogênio e potássio. Embora teores de K, Fe e B variou entre as doses de $\mathrm{N}$ e K aplicadas as plantas não apresentaram deficiência nutricional. As aplicações de fertilizantes em doses crescentes contribuem para o acúmulo de sais no solo, aumentando o risco de salinização.

Palavras-chave: Cucumis melo L., melão Cantaloupe, salinidade 


\section{INTRODUCTION}

In addition to promoting the diversification of agricultural activities, melon plays an important socioeconomic role in producing regions (Santos et al., 2014; Silva et al., 2014), as it is a guarantee of work, employment and income for rural men, mainly in the dry period.

Researchers such as Callegari et al. (2012) stated that fertigation reduces nutrient losses by 25 to $50 \%$, mainly due to fractionation of the fertilization recommendation in various applications during the crop cycle.

However, the traditional management of fertigation has led to excessive losses and applications, justifying the need for better control to guarantee both economic and environmental improvement (Anjos et al., 2015; Gomes et al., 2015).

An alternative to this traditional management would be to control fertigation by concentrating nutrients in the soil solution (Oliveira et al., 2013) or in irrigation water in a high frequency system, such as drip (Anjos et al., 2015).

Nitrogen $(\mathrm{N})$ and potassium $(\mathrm{K})$ are the nutrients most required by the melon (Damasceno et al., 2012; Silva et al., 2014; Oliveira et al., 2016) and consequently, are those applied in a greater proportion in fertigation.

In this context, it is known that the crop response occurs from a certain amount of nutrient available in the soil solution, and this depends on the amount of fertilizer applied in the irrigation water (Callegari et al., 2012; Pereira Filho et al., 2014).

For Damasceno et al. (2012) the efficiency of fertigation occurs when there is a balance between quantity of nutrients and quality of water applied in order to supply the needs of the crop, without causing the accumulation of salts in the soil.

In view of the above, the objective of this study was to evaluate the productivity and leaf contents of nutrients of melon crop and soil fertility that presents high potassium concentration, when fertigated with doses of nitrogen and potassium based on their average concentration in the applied irrigation water.

\section{Material ANd Methods}

The experiment was conducted at Cumaru Farm at coordinates $5^{\circ} 33^{\prime} 35^{\prime \prime} \mathrm{S}, 37^{\circ} 11^{\prime} 57^{\prime \prime} \mathrm{W}$ in the municipality of Upanema, RN, Brazil, between the months of December 2017 and February 2018 on soil classified as Inceptisol.

For soil characterization, initially a sample composed of soil was collected, at a depth of 0 to $0.20 \mathrm{~m}$, in all experimental area and chemical attributes were determined: $\mathrm{N}$-total $=0.49 \mathrm{~g} \mathrm{~kg}^{-1} ; \mathrm{pH}$ = 8.2; CEes $=1.95 \mathrm{dS} \mathrm{m}^{-1} ;$ M. O. $=1.62 \mathrm{~g} \mathrm{~kg}^{-1} ; \mathrm{P}=4.7 \mathrm{mg} \mathrm{dm}^{3}$; $\mathrm{K}=143.1 \mathrm{mg} \mathrm{dm}{ }^{3} ; \mathrm{Na}=81.5 \mathrm{mg} \mathrm{dm}{ }^{3} ; \mathrm{Ca}=8.7 \mathrm{cmol}_{\mathrm{c}} \mathrm{dm}^{3} ; \mathrm{Mg}$ $=2.2 \mathrm{cmol}_{\mathrm{c}} \mathrm{dm}^{3} ; \mathrm{Al}=0 \mathrm{cmol}_{\mathrm{c}} \mathrm{dm}^{3} ; \mathrm{H}+\mathrm{Al}=0 \mathrm{cmol}_{\mathrm{c}} \mathrm{dm}^{-3}$ and, $\mathrm{SB}=11.62 \mathrm{cmol}_{\mathrm{c}} \mathrm{dm}^{3}$ and PST $=3 \%$ were calculated, following the methodologies proposed by EMBRAPA (2017).

The characteristics of irrigation water were also analyzed, verifying $\mathrm{CE}=1.44 \mathrm{dS} \mathrm{m}{ }^{-1} ; \mathrm{pH}=6.8 ; \mathrm{Na}=3.1 \mathrm{mmol}_{\mathrm{c}} \mathrm{L}^{-1} ; \mathrm{K}=$ $0.11 \mathrm{mmol}_{\mathrm{c}} \mathrm{L}^{-1} ; \mathrm{Ca}=7.5 \mathrm{mmol}_{\mathrm{c}} \mathrm{L}^{-1} ; \mathrm{Mg}=4.5 \mathrm{mmol}_{\mathrm{c}} \mathrm{L}^{-1} ; \mathrm{Cl}=$ $6.2 \mathrm{mmol}_{c} \mathrm{~L}^{-1} ; \mathrm{HCO}_{3}=9.0 \mathrm{mmol}_{c} \mathrm{~L}^{-1}$.

The experimental design used was in randomized blocks with five treatments and six repetitions. The treatments corresponded to the combinations of concentrations of $\mathrm{N}$ and $\mathrm{K}$ added to the irrigation water, and were thus defined: $\mathrm{T} 1=$ $0 \mathrm{mg} \mathrm{L}^{-1}$ of $\mathrm{N}$ and $\mathrm{K} ; \mathrm{T} 2=50 \mathrm{mg} \mathrm{L}^{-1} \mathrm{~N}$ and $0 \mathrm{mg} \mathrm{L}^{-1}$ of $\mathrm{K}$; T3 $=50 \mathrm{mg} \mathrm{L}^{-1}$ of $\mathrm{N}$ and $54 \mathrm{mg} \mathrm{L}^{-1}$ of K; $\mathrm{T} 4=0 \mathrm{mg} \mathrm{L}^{-1}$ of $\mathrm{N}$ and $54 \mathrm{mg} \mathrm{L}^{-1}$ of K and T5 $=100 \mathrm{mg} \mathrm{L}^{-1}$ of $\mathrm{N}$ and $108 \mathrm{mg} \mathrm{L}^{-1}$ of $\mathrm{K}$.

The combinations for $\mathrm{N}$ and $\mathrm{K}$ were defined from studies already conducted under similar conditions, such as Silva Júnior et al. (2016). Each experimental unit was composed of $6 \mathrm{~m}$ row, containing 20 plants, and the useful area of the plot was the 14 central plants corresponding to a total of $8.4 \mathrm{~m}^{2}$.

In order to prepare the area for conducting the experiment, harrowing, furrowing, application of foundation fertilization (18-90-00) $\mathrm{kg} \mathrm{ha}^{-1}$ were carried out and lifting was done with the aid of a tractor.

Then, the drip irrigation system was installed with emitters spaced $0.30 \mathrm{~m}$ and flow rate of $1.4 \mathrm{~L} \mathrm{~h}^{-1}$, application of mulching with black-white double-sided polyethylene film and planting of Cantaloupe melon seeds, grow crops Olimpic Express with $2.0 \times 0.3 \mathrm{~m}$ spacing.

During the experiment, weeding was carried out throughout the area, in order to keep the crop free from invasive plants, the manifestation of pests and diseases was also observed throughout the cycle and was controlled through the application of chemical products as required.

The daily irrigation depths were determined by estimating the crop evapotranspiration (ETc), calculated from the reference evapotranspiration (ETo) obtained by the PenmanMonteith equation - FAO, and the cultivation coefficient estimated by the dual kc methodology (Allen et al., 2006) and adjustments made from the matrix potential measurements determined three times a week, using tensiometers installed at 15 and $30 \mathrm{~cm}$ depth, in order to maintain their values between -6 and $-30 \mathrm{kPa}$.

A basal cultivation coefficient (Kcb) was adopted for phase III $(\mathrm{KcbIII}=0.9)$ and end of cycle $(\mathrm{KcbF}=0.6)$ and the length of phases I, II, III and IV, were respectively, 20, 15, 20 and 15 days. The total depth was increased by $10 \%$ considering the application efficiency of the irrigation system, which includes the uniformity coefficient and the need for leaching.

On the occasion of the occurrence of rain, irrigation was suspended, returning to irrigate when the average water tensions in the soil, measured in the different treatments, reached a value greater than $10 \mathrm{kPa}$. Thus, until the end of the cycle (70 days) a total depth of $184 \mathrm{~mm}$ of water was applied.

Fertigation was calculated based on the volume of water to be applied between one fertigation and another and the average concentration was established for each treatment, being performed twice a week, where each application concentrated the estimated dosage to an average concentration for the amount of irrigation water estimated to be applied until the previous day scheduled for the next fertigation. The quantity of water was maintained according to the water requirement of the crop estimated by the ETc in the time interval considered.

For the application of the fertilizers, negative pressure or pump suction was used, placing in the pump suction pipe a register and a derivation line with register and in the moment of fertilizer application, the suction line was closed and the derivation line was opened, thus sucking the previously prepared solution in a $20 \mathrm{~L}$ container. 
Fertigation was applied for a time sufficient for the uniformity of application of nutrients in the area to show uniformity greater than $85 \%$. After the application of fertilizers in each treatment, irrigation was supplemented only with water throughout the experiment, to meet the application of the irrigation depth necessary for the crop.

The nitrogen sources applied throughout the melon cultivation cycle were commercial fertilizers urea (67\% of the total $\mathrm{N}$ applied) and $\mathrm{Ca}\left(\mathrm{NO}_{3}\right)_{2}$ (33\% of the total $\mathrm{N}$ applied), performed between 15 and 50 days after sowing, where $160 \mathrm{~mm}$ of irrigation was applied. In treatment $\mathrm{T} 5$ the mean concentration of $\mathrm{N}$ was $100 \mathrm{mg} \mathrm{L}^{-1}$, corresponding to an application of $160 \mathrm{~kg} \mathrm{ha}^{-1}$ of $\mathrm{N}$.

For the supply of potassium, commercial fertilizers $\mathrm{K}_{2} \mathrm{SO}_{4}$ (14.5\% of total applied $\mathrm{K}$ ) and $\mathrm{KCl}(85.5 \%$ of total applied $\mathrm{K}$ ) were used as the source, being applied until the end of the cycle in treatment T5 (concentration average of $108 \mathrm{mg} \mathrm{L}^{-1}$ of $\mathrm{K}$ ) equivalent to $206 \mathrm{~kg} \mathrm{ha}^{-1}$ of $\mathrm{K}_{2} \mathrm{O}$.

To assess leaf nutrient content, samples of the diagnostic leaf (fifth leaf of the main branch) were collected from each plant at 35 days after planting, and sent to the laboratory, where they were washed and dried in a forced air circulation oven, at a temperature of $65^{\circ} \mathrm{C}$, until constant weight is reached.

The samples were crushed in a mill and submitted to sulfuric digestion to determine total nitrogen $(\mathrm{N})$, phosphorus $(\mathrm{P})$, potassium $(\mathrm{K})$, calcium $(\mathrm{Ca})$, magnesium $(\mathrm{Mg})$, iron $(\mathrm{Fe})$ and manganese $(\mathrm{Mn})$, and dry digestion was used to determine the levels of sulfur (S), boron (B) and sodium (Na), according to EMBRAPA (2009).

The contents of $\mathrm{Ca}, \mathrm{Mg}, \mathrm{Fe}$ and $\mathrm{Mn}$ were determined by direct reading in atomic absorption spectrometry. The $\mathrm{Na}$ and $\mathrm{K}$ by flame photometer. The P, B and S by spectrophotometry. Total $\mathrm{N}$ was determined by the micro-Kjeldhal method.

To evaluate soil fertility, soil samples were collected at the end of the crop cycle in the $0-20 \mathrm{~cm}$ layer, totaling 30 samples. All samples were duly identified, put to dry in the open air, ground, sieved, and analyzed chemically, following the methodology proposed by EMBRAPA (2017).

The quantification of $\mathrm{pH}, \mathrm{CE}$ and mineral $\mathrm{N}\left(\mathrm{N}-\mathrm{NO}_{3}\right.$ and $\mathrm{N}-\mathrm{NH}_{4}$ ) was performed on the saturation paste extract; $\mathrm{P}, \mathrm{K}$ and $\mathrm{Na}$, by extraction, with Melhich-1 solution; $\mathrm{Ca}, \mathrm{Mg}$ and $\mathrm{Al}$ by extraction with $1 \mathrm{M} \mathrm{KCl}$ solution; o $\mathrm{H}+\mathrm{Al}$ extracted with calcium acetate solution at pH 7.0 (EMBRAPA, 2017).
The contents of $\mathrm{Na}, \mathrm{K}$ and $\mathrm{Ca}$ in the saturation paste solution were also determined.

The fruits were harvested 56 days after planting, and all fruits were weighed and counted. Fruits with a mass greater than $1.0 \mathrm{~kg}$ and without defects (irregular shape, cracked) were considered commercial and the others non-commercial.

The total productivity (PRTOT) was determined by weighing all fruits per unit area and expressed in $\mathrm{kg} \mathrm{ha}^{-1}$ and the commercial productivity (PRCOM) determined by weighing all fruits with commercial standard expressed in $\mathrm{kg} \mathrm{ha}^{-1}$.

The results were submitted to analysis of variance (ANOVA), and the means were compared by the Tukey test $(\mathrm{p} \leq 0.05)$.

\section{Results AND Discussion}

Table 1 shows the analysis of variance for the foliar contents of nutrients and averages per treatment. Significant effects were observed for the following characteristics: K, Fe and B. The other characteristics did not differ between treatments.

For N (Table 1), no significant differences were observed between treatments, with an overall mean of $47.54 \mathrm{~g} \mathrm{~kg}^{-1}$. It was assumed that the lack of response to treatments in plants that received $\mathrm{N}$ (T2, T3 and T5), may be related to the disposition of this nutrient in the plant, that is, its mobility in the tissues due to dilution effects as the plant develops.

Likewise, according to Cantarella (2007), this lack of effect may be related to the possible accumulation of inorganic $\mathrm{N}$ in the subsoil in crops that received $\mathrm{N}$ above the dose for the maximum response. According to Dechen \& Nachtigal (2006), the content considered ideal for the $\mathrm{N}$ in plants varies from 20 to $50 \mathrm{~g} \mathrm{~kg}^{-1}$.

Oliveira et al. (2015) observed values similar to the averages presented in this study for $\mathrm{N}$, when they studied the mineral nutrition of peppers submitted to different fertigation management, with an average of $47.4 \mathrm{~g} \mathrm{~kg}^{-1}$ being presented for the fertigation, from the absorption rate of the crop.

Another justification may be due to the fact that plants up to 35 days accumulate less than $25 \%$ of the $\mathrm{N}$ absorbed in the cycle (Damasceno et al., 2012), and that in this period the amount of $\mathrm{N}$ applied in fertigation also only represented about $20 \%$, so that the $\mathrm{N}$ that was applied in the foundation and part of the total $\mathrm{N}$ present in the mineralized soil has

Table 1. Summary of analysis of variance and averages of leaf nutrient content in melon irrigated with $\mathrm{N}$ and $\mathrm{K}$ doses

\begin{tabular}{|c|c|c|c|c|c|c|c|c|c|c|c|}
\hline \multirow{2}{*}{ SV } & \multirow{2}{*}{ GL } & $\bar{N}$ & K & $\mathrm{Ca}$ & $\mathrm{Mg}$ & S & $\mathbf{P}$ & $\mathrm{Fe}$ & $M n$ & B & $\mathrm{Na}$ \\
\hline & & \multicolumn{10}{|c|}{ F Statistics } \\
\hline Block & 5 & $0.07^{\text {ns }}$ & $1.12^{\mathrm{ns}}$ & $1.12^{\mathrm{ns}}$ & $0.68^{\text {ns }}$ & $1.74^{\text {ns }}$ & $0.14^{\text {ns }}$ & $1.04^{\mathrm{ns}}$ & $2.32^{\text {ns }}$ & $0.21^{\text {ns }}$ & $2.76^{*}$ \\
\hline Treatment & 4 & $1.25^{\mathrm{ns}}$ & $5.67^{*}$ & $0.80^{\text {ns }}$ & $1.15^{\text {ns }}$ & $2.16^{\text {ns }}$ & $1.06^{n s}$ & $3.83^{*}$ & $0.81^{\text {ns }}$ & $4.80^{*}$ & $0.42^{\mathrm{ns}}$ \\
\hline $\begin{array}{l}\text { Error } \\
\text { CV (\%) }\end{array}$ & 20 & 10.59 & 7.13 & 12.60 & 12.15 & 10.10 & 15.02 & 23.68 & 27.85 & 31.49 & 10.04 \\
\hline \multirow{2}{*}{\multicolumn{2}{|c|}{ Treatments }} & \multicolumn{10}{|c|}{ Means } \\
\hline & & \multicolumn{4}{|c|}{$\mathrm{g} \mathrm{kg}^{-1}$} & $\mathrm{mg} \mathrm{kg}^{-1}$ & $\mathrm{~g} \mathrm{~kg}^{-1}$ & \multicolumn{4}{|c|}{$\mathrm{mg} \mathrm{kg}^{-1}$} \\
\hline \multicolumn{2}{|c|}{ T1 } & $45.21 \mathrm{a}$ & $28.22 b$ & $15.65 a$ & $2.31 \mathrm{a}$ & $6.28 \mathrm{a}$ & $4.09 \mathrm{a}$ & $285.83 \mathrm{a}$ & $172.30 \mathrm{a}$ & $49.71 \mathrm{~b}$ & $943.77 \mathrm{a}$ \\
\hline \multicolumn{2}{|c|}{ T2 } & $49.80 \mathrm{a}$ & $29.58 b$ & $15.76 \mathrm{a}$ & $2.36 \mathrm{a}$ & $6.00 \mathrm{a}$ & $3.97 \mathrm{a}$ & $191.54 \mathrm{~b}$ & $187.04 \mathrm{a}$ & $64.16 \mathrm{~b}$ & $943.77 \mathrm{a}$ \\
\hline \multicolumn{2}{|c|}{ T3 } & $48.71 \mathrm{a}$ & $30.41 \mathrm{ab}$ & $14.13 \mathrm{a}$ & $2.20 \mathrm{a}$ & $6.43 \mathrm{a}$ & $3.55 \mathrm{a}$ & $214.34 a b$ & $172.11 \mathrm{a}$ & $74.12 a b$ & $979.21 \mathrm{a}$ \\
\hline \multicolumn{2}{|c|}{ T4 } & $44.92 \mathrm{a}$ & $33.65 \mathrm{a}$ & $14.75 \mathrm{a}$ & $2.47 \mathrm{a}$ & $6.59 \mathrm{a}$ & $3.72 \mathrm{a}$ & 179.06 b & $141.13 \mathrm{a}$ & $69.48 a b$ & $943.77 \mathrm{a}$ \\
\hline \multicolumn{2}{|c|}{ T5 } & $49.07 \mathrm{a}$ & $29.08 b$ & $14.70 \mathrm{a}$ & $2.17 \mathrm{a}$ & $7.05 \mathrm{a}$ & $3.65 \mathrm{a}$ & $225.72 a b$ & $160.92 \mathrm{a}$ & $105.20 \mathrm{a}$ & $908.33 \mathrm{a}$ \\
\hline \multicolumn{2}{|c|}{ Overall mean } & 47.54 & 30.19 & 15.00 & 2.30 & 6.47 & 3.79 & 219.30 & 166.70 & 72.53 & 943.77 \\
\hline \multicolumn{2}{|c|}{ MSD (5\%) } & 8.69 & 3.72 & 3.26 & 0.48 & 1.13 & 0.98 & 89.69 & 80.17 & 39.44 & 163.55 \\
\hline
\end{tabular}

* - Significant at $\mathrm{p} \leq 0.05$ by the F-test; $\mathrm{ns}$ - Not significant; means followed by the same letter in the column do not differ at $\mathrm{p} \leq 0.05$ by the Tukey test; SV - Source of variation $\mathrm{T} 1-0 \mathrm{mg} \mathrm{L}{ }^{-1}$ of N and K; T2 - $50 \mathrm{mg} \mathrm{L}^{-1}$ of N and $0 \mathrm{mg} \mathrm{L}^{-1}$ of K; T3 - $50 \mathrm{mg} \mathrm{L}^{-1}$ of N and $54 \mathrm{mg} \mathrm{L}^{-1}$ of K; T4 - $0 \mathrm{mg} \mathrm{L}^{-1}$ of N and $54 \mathrm{mg} \mathrm{L}^{-1}$ of K; T5 -100 mg L-1 of N and $108 \mathrm{mg} \mathrm{L}^{-1}$ of K 
already represented a significant amount for all treatments, already being sufficient to supply it in this period. Possibly, the recommendations for leaf diagnosis, which is performed at a given plant age for conventional fertilization, should not be an adequate recommendation when applying the nutrient in fertigation, as its supply follows its absorption rate.

For the $\mathrm{K}$ content in the leaf tissue (Table 1), the highest average was found in treatment T4 with $33.65 \mathrm{~g} \mathrm{~kg}^{-1}$, not different from treatment $\mathrm{T} 3$, and different from the other treatments, which in turn were statistically equal (T1, T2, T3 and $\mathrm{T} 5$ ).

This behavior shows that there was no increase of $\mathrm{K}$ in leaf tissue for the greater quantity of this nutrient applied via fertigation, i.e., treatment $\mathrm{T} 5\left(108 \mathrm{mg} \mathrm{L}^{-1}\right)$. However, it was verified that $\mathrm{K}$ concentrations remained within the recommended range of 20 to $50 \mathrm{~g} \mathrm{~kg}^{-1}$ of mass in the vegetative parts, values pointed out by Meurer (2006), as a range that provides optimal plant growth.

Damasceno et al. (2012) observed that potassium was the most required nutrient for melons, when they studied the growth and nutrient absorption rate of Cantaloupe melons, type 'Harper' fertigated with doses of $\mathrm{N}$ and $\mathrm{K}$.

For Fe in leaf tissue (Table 1), a higher mean for T1 treatment was observed at $285.8 \mathrm{mg} \mathrm{kg}^{-1}$ and lower mean for treatment T4 with $179.1 \mathrm{mg} \mathrm{kg}^{-1}$, and these means were statistically different from each other. Treatment $\mathrm{T} 1$ was similar to treatments $\mathrm{T} 3$ and $\mathrm{T} 5$, and $\mathrm{T} 4$ treatment similar to $\mathrm{T} 2$, $\mathrm{T} 3$ and $\mathrm{T} 5$ treatments.

These results show that the levels of $\mathrm{Fe}$ are above the range of 50 to $100 \mathrm{mg} \mathrm{kg}^{-1}$, indicated as adequate for normal plant growth (Dechen \& Nachtigal, 2006).

Thus, according to the observed values, it appears that the soil under study has high concentrations of $\mathrm{Fe}$, due to its higher degree of weathering (Silva, 2018), which even for slightly alkaline soil pH does not limit the availability of Fe to plants. However, the non-application of fertilizers in fertigation (T1), kept the salinity of the soil below the threshold salinity of the crop (Medeiros et al., 2011), without providing saline stress, unlike other treatments (Table 2), which may have contributed to a greater absorption, which was verified for all treatments.
For the $\mathrm{B}$ content in the leaf tissue, the highest mean observed is in treatment T5 $\left(105.2 \mathrm{mg} \mathrm{kg}^{-1}\right)$, which is statistically higher than that observed in treatments $\mathrm{T} 1$ (49.7 $\left.\mathrm{mg} \mathrm{kg}^{-1}\right)$ and T2 $\left(64.2 \mathrm{mg} \mathrm{kg}^{-1}\right)$. It is worth mentioning that in addition to the history of application of $\mathrm{B}$ in previous plantings, applications were made in fertigation at 15 and 25 days after sowing, with $0.5 \mathrm{~kg} \mathrm{ha}^{-1}$ of $\mathrm{B}$.

Considering the $\mathrm{B}$ concentrations observed in the present study, it was observed that the values are above the appropriate range for plant development, which ranges from 30 to $50 \mathrm{mg} \mathrm{kg}^{-1}$ (Dechen \& Nachtigal, 2006).

According to Miranda et al. (2006), the occurrence of high concentrations of micronutrients may be due to the intense application, over the years, of various types of fertilizers, including micronutrients, and of agrochemicals, mainly fungicides.

Oliveira et al. (2016) observed peaks of micronutrient accumulation when they evaluated nutrient partitioning and accumulation in fertigated yellow melon under semi-arid conditions, and a cumulative total of $23.5 \mathrm{mg} \mathrm{kg}^{-1}$ was observed for B.

Table 2 shows the analysis of variance and the averages of the chemical attributes of the soil in the $0-20 \mathrm{~cm}$ layer. Significance was observed in the characteristics $\mathrm{pH}, \mathrm{CE}$, exchangeable $\mathrm{K}, \mathrm{N}, \mathrm{K}$ and $\mathrm{Ca}$ in the saturation extract. High values for the coefficient of variation (CV) were also observed.

These high CV values can be attributed to different factors: soil variability: as the soil is of calcareous origin and has many stains caused by anthills, which are random and occur over distances often less than $10 \mathrm{~m}$, at these points the calcium from the source rock (limestone) or from horizon $\mathrm{C}$ rises to the surface, increasing its content and reducing those of $\mathrm{Mg}$ and $\mathrm{K}$. In the case of $\mathrm{P}$, it may be due to the application of the element having been at the bottom of the groove, which leads to sampling errors, considering that it was performed with a 1.5" Dutch auger; and in the case of $\mathrm{Mg}$ still the analytical method of determination is by recording the difference between the sum of $\mathrm{Ca}$ and $\mathrm{Mg}$.

For soil $\mathrm{pH}$ (Table 2), the highest mean was found in treatment $\mathrm{T} 1$, being statistically different from treatments

Table 2. Summary of analysis of variance and means of chemical attributes of fertigated soil with doses of $\mathrm{N}$ and $\mathrm{K}$, in the 0-20 cm layer

\begin{tabular}{|c|c|c|c|c|c|c|c|c|c|c|c|c|}
\hline \multirow{2}{*}{ SV } & \multirow{2}{*}{ GL } & \multirow{2}{*}{ pH } & \multirow{2}{*}{ ECse } & \multicolumn{5}{|c|}{ Extractables } & \multicolumn{4}{|c|}{ Saturation paste extract } \\
\hline & & & & $\mathbf{P}$ & $\mathrm{K}$ & $\mathrm{Ca}$ & $\mathrm{Mg}$ & $\mathrm{Na}$ & $\mathbf{N}$ & K & $\mathrm{Ca}$ & $\mathrm{Na}$ \\
\hline & & \multicolumn{11}{|c|}{ F Statistics } \\
\hline Block & 5 & $1.54^{\mathrm{ns}}$ & $0.41^{\mathrm{ns}}$ & $0.44^{\mathrm{ns}}$ & $1.86^{\mathrm{ns}}$ & $2.88^{\star}$ & $0.28^{\text {ns }}$ & $0.30^{\text {ns }}$ & $0.52^{\mathrm{ns}}$ & $1.29^{\text {ns }}$ & $0.87^{\mathrm{ns}}$ & $0.57^{\mathrm{ns}}$ \\
\hline Treatment & 4 & $4.66^{\star}$ & $17.60^{\star}$ & $1.83^{\text {ns }}$ & $9.36^{*}$ & $1.80^{\text {ns }}$ & $1.27^{\text {ns }}$ & $1.23^{\text {ns }}$ & $36.72^{*}$ & $19.53^{*}$ & $34.65^{\star}$ & $1.57^{\mathrm{ns}}$ \\
\hline Error & 20 & & & & & & & & & & & \\
\hline CV (\%) & & 2.35 & 22.74 & 76.93 & 47.65 & 14.56 & 79.47 & 30.09 & 33.41 & 60.89 & 23.87 & 32.60 \\
\hline \multirow{2}{*}{\multicolumn{2}{|c|}{ Treatments }} & \multicolumn{11}{|c|}{ Means } \\
\hline & & - & dS $m^{-1}$ & \multicolumn{2}{|c|}{$\mathrm{mg} \mathrm{dm^{-3 }}$} & \multicolumn{2}{|c|}{$\mathrm{cmol}_{\mathrm{C}} \mathrm{dm}^{-3}$} & $\mathrm{mg} \mathrm{dm}^{-3}$ & \multicolumn{4}{|c|}{$\mathrm{mg} \mathrm{L}^{-1}$} \\
\hline $\mathrm{T1}$ & & $7.84 \mathrm{a}$ & $1.90 \mathrm{C}$ & $44.96 \mathrm{a}$ & $124.29 \mathrm{c}$ & $10.29 \mathrm{a}$ & $1.50 \mathrm{a}$ & $104.92 \mathrm{a}$ & $13.89 b$ & $17.08 \mathrm{~b}$ & $73.13 d$ & $147.21 \mathrm{a}$ \\
\hline T2 & & $7.64 \mathrm{ab}$ & $4.05 b$ & $67.27 \mathrm{a}$ & $112.17 \mathrm{C}$ & $11.13 \mathrm{a}$ & $1.01 \mathrm{a}$ & $94.52 \mathrm{a}$ & $315.29 \mathrm{a}$ & $19.97 \mathrm{~b}$ & 300.58 bc & $173.59 \mathrm{a}$ \\
\hline T3 & & $7.53 \mathrm{~b}$ & $4.60 \mathrm{~b}$ & $17.26 \mathrm{a}$ & $194.19 b$ & $9.85 \mathrm{a}$ & $2.03 \mathrm{a}$ & $87.20 \mathrm{a}$ & $278.11 \mathrm{a}$ & $77.70 \mathrm{~b}$ & $428.36 \mathrm{~b}$ & $185.33 \mathrm{a}$ \\
\hline T4 & & $7.70 \mathrm{ab}$ & $3.48 b c$ & $42.42 \mathrm{a}$ & $349.72 a b$ & $10.39 \mathrm{a}$ & $0.82 \mathrm{a}$ & $110.23 a$ & $22.43 b$ & $100.99 b$ & $259.60 \mathrm{C}$ & $210.18 \mathrm{a}$ \\
\hline T5 & & $7.43 \mathrm{~b}$ & $6.22 \mathrm{a}$ & $38.31 \mathrm{a}$ & $442.33 \mathrm{a}$ & $12.03 \mathrm{a}$ & $1.17 \mathrm{a}$ & $78.34 \mathrm{a}$ & $268.47 \mathrm{a}$ & $287.40 \mathrm{a}$ & $573.51 \mathrm{a}$ & $140.23 \mathrm{a}$ \\
\hline \multicolumn{2}{|c|}{ Overall means } & 7.63 & 4.05 & 42.05 & 244.54 & 10.74 & 1.30 & 95.00 & 179.64 & 100.63 & 327.04 & 171.31 \\
\hline \multicolumn{2}{|c|}{$\operatorname{MSD}(5 \%)$} & 0.31 & 1.59 & 55.86 & 201.20 & 2.70 & 1.79 & 49.39 & 103.65 & 105.82 & 134.79 & 96.43 \\
\hline
\end{tabular}

* - Significant at $\mathrm{p} \leq 0.05$ by the F test; $n s$ - Not significant; Means followed by the same letter in the column do not differ at $\mathrm{p} \leq 0.05$ by the Tukey test; SV - Source of variation; T1

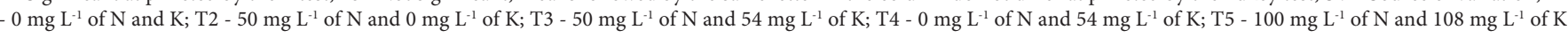


$\mathrm{T} 3$ and T5 and similar to treatments T2 and T4. The T5 and $\mathrm{T} 3$ treatments had the lowest $\mathrm{pH}$ averages, a fact that can be attributed, most likely, to the urea nitrification process applied in these treatments, which favors the $\mathrm{pH}$ reduction.

Thus, the increment of the doses of $\mathrm{N}$ and $\mathrm{K}$ reduced the $\mathrm{pH}$ of the soil in relation to the treatment $\mathrm{T} 1$, which may have provided a better environment for the plants, since the $\mathrm{pH}$ remained close to the range that favors their development; according to Cometti et al. (2006), plants can withstand $\mathrm{pH}$ between 4.5 and 7.5 without great physiological effects.

Another point to consider is that regardless of the treatment, there was a reduction in the initial $\mathrm{pH}$ value, which may be associated with the management of fertigation, given that the trend would be to increase the $\mathrm{pH}$ since the irrigation water had a high bicarbonate index. Another possibility to consider is the mineralization of organic material present in the soil, where $\mathrm{H}^{+}$ions are released, favoring such behavior for $\mathrm{pH}$.

The electrical conductivity in the soil saturation extract (ECse) showed the highest average for the T5 treatment with $6.22 \mathrm{dS} \mathrm{m}^{-1}$ and the lowest average for the T1 treatment with $1.90 \mathrm{dS} \mathrm{m}^{-1}$. This behavior is as expected given the amount of fertilizers applied in the T5 treatment, indicating that fertilizer applications in greater quantities favored the accumulation of salts, and, over time and successive cycles, may lead to the salinization of producing areas.

The increase in soil electrical conductivity was also observed by Gomes et al. (2015), when applying potassium doses in strawberry cultivation, saline effect was observed on the soil and toxicity to plants at the highest dose of potassium applied.

Anjos et al. (2015) who also observed an increase in electrical conductivity from potassium fertilization, emphasized the saline effect of $\mathrm{KCl}$ applied via fertigation. In view of this, what was observed was a greater increase in ECse for a greater amount of applied nutrients and considering that $\mathrm{T} 5$ was where the highest dose of $\mathrm{K}$ was applied, it is possible that potassium contributed more effectively to the increase in the electrical conductivity of the soil, as its main applied source was $\mathrm{KCl}$.

The increase in ECse was, most likely, the factor that limited the increase in production in treatments that received larger amounts of fertilizers, causing a non-significant effect on production (Table 3 ).

The phosphorus (P) content did not present significant differences between treatments and obtained an overall average of $42.05 \mathrm{mg} \mathrm{dm}^{3}$, considered high. The coefficient of variation (CV) of the statistical analysis was very high, which may have contributed to the non-detection of significant differences in the applied test. However, the most expected response would be the non-statistical difference between the treatments, if they did not promote variations in the absorption of this nutrient by plants or other changes in soil characteristics such as $\mathrm{pH}$, which in all treatments were slightly alkaline.

For extractable potassium $(\mathrm{K})$ content, in treatments where $\mathrm{K}$ was not applied, there was a lower concentration of $\mathrm{K}$ in the soil (T1 and T2). Where K was applied in higher concentrations there was a greater increase of $\mathrm{K}$ in the soil (T3, T4 and T5). Thus, the $\mathrm{T} 5$ treatment was the one that provided the highest average $442.33 \mathrm{mg} \mathrm{dm}^{-3}$, and the lowest average was observed for the $\mathrm{T} 2$ treatment with $112.17 \mathrm{mg} \mathrm{dm}^{-3}$, an already high content and therefore there may have been no response of the crop to the increasing concentrations of $\mathrm{K}$ in the irrigation water.

In relation to the initial content of $\mathrm{K}$, there was a reduction in the values in the treatments that did not receive potassium fertilization and gains for those that did. In general, what has been observed in this type of soil is that most of the extracted $\mathrm{K}$ is exchangeable and the minimum remains in solution. That is, the solid fractions of the soil have a very high affinity for $\mathrm{K}$ (Silva Júnior et al., 2016), so to be able to raise the potassium in the soil solution, it is necessary to apply a lot of $\mathrm{K}$, which leads to soil salinization.

It was observed that the highest dose of K provided higher concentration of this nutrient in the soil and this was not statistically different from the application of half of the $\mathrm{K}$ concentration, applied individually (T4). This behavior may be related to the interaction of this nutrient with the colloids of the soil and these with the solution, as well as with the ability that clayey soils have in retaining this nutrient.

According to Matos et al. (2013), although $\mathrm{K}$ is a monovalent cation, at high concentrations it allows the displacement of bivalent cations, favoring its concentration in the exchange complex.

The contents of extractable $\mathrm{Na}, \mathrm{Ca}$ and $\mathrm{Mg}$ and, soluble $\mathrm{Na}$ (Table 2), did not differ between treatments. There are general averages of $95.04 \mathrm{mg} \mathrm{dm}^{-3}$ for $\mathrm{Na}, 10.74 \mathrm{mg} \mathrm{dm}^{-3}$ for $\mathrm{Ca}$ and $1.30 \mathrm{mg} \mathrm{dm}^{-3}$ for $\mathrm{Mg}$, and $171.31 \mathrm{mg} \mathrm{L}^{-1}$ for soluble $\mathrm{Na}$. Considering the exchangeable $\mathrm{Ca}$ and $\mathrm{Mg}$ levels, the levels are considered high.

For nitrogen $\left(\mathrm{N}-\mathrm{NH}_{4}+\mathrm{NO}_{3}\right)$ evaluated in the soil saturation paste extract (Table 2), as expected, higher increments were observed for treatments that received nitrogen fertilization. The treatments that received $\mathrm{N}$ (T2, T3 and T5) were statistically different to the others (T1 and T4) and equal to each other, thus significant increments were not observed for the greater amount of $\mathrm{N}$ applied (treatment $\mathrm{T} 5$ ).

However, the differences observed for $\mathrm{N}$ did not imply greater increments of this nutrient in the melon leaf, nor in higher yields for the treatments that received $\mathrm{N}$, as seen in Tables 1 and 3.

The highest mean for $\mathrm{N}$ was observed in T2 with $315.29 \mathrm{mg} \mathrm{L}^{-1}$ and the lowest mean for T1 with $13.89 \mathrm{mg} \mathrm{L}^{-1}$. Coelho et al. (2014) concluded that the increase in the concentration of nitrogen fertilizer in the irrigation water provided an increase in the nitrate ion concentration, both in the soil solution and in the saturation extract.

For soluble $\mathrm{K}$ and $\mathrm{Ca}$, evaluated in the saturation paste solution, significant differences were found, with the highest averages being $287.40 \mathrm{mg} \mathrm{L}^{-1}$ of $\mathrm{K}$ and $573.51 \mathrm{mg} \mathrm{L}^{-1}$ of $\mathrm{Ca}$ for treatment $\mathrm{T} 5$, which differed from other treatments. The lowest averages were observed in treatment $\mathrm{T} 1$, with $\mathrm{K}$ being $17.08 \mathrm{mg} \mathrm{L}^{-1}$, not differing from the others, and for $\mathrm{Ca}, 73.13 \mathrm{mg} \mathrm{L}^{-1}$, not differing from $\mathrm{T} 2$ and $\mathrm{T} 3$.

This behavior observed for potassium in solution is as expected, with the highest concentration observed in the highest applied dose (T5 treatment), confirming the hypothesis 
that a higher concentration in irrigation water will increase the content in the soil solution.

In the case of calcium, the lower CV favored the detection of significant differences, with T2 being similar to T3 and T4. This behavior is justified because it was used as a nutritional source of part of $\mathrm{N}$, calcium nitrate.

Another justification is that there is greater availability of this cation $(\mathrm{Ca})$ for the soil solution when $\mathrm{K}$ is applied, and as the treatments $\mathrm{T} 2$ and $\mathrm{T} 3$ received the same amounts of $\mathrm{N}$ and $\mathrm{T} 3$ and $\mathrm{T} 4$ the same amounts of $\mathrm{K}$, the contributions given from each nutrient source to $\mathrm{Ca}$, were similar to the displacement of calcium caused by the action of $\mathrm{K}$ in the soil.

Table 3 presents the summary of the analysis of variance and the averages for melon production. It was observed that, for the F test at 0.05 significance level, total and commercial productivity did not differ between the treatments studied.

This behavior is most likely due to the rate of mineralization of organic matter and the consequent supply of nitrogen to the crop, and the fact that the soil already has exchangeable potassium at a level considered high and that the applications of nitrogen and potassium doses via fertigation have provided a substantial increase of soil salinity (ECse), as values are greater than $2.2 \mathrm{dS} \mathrm{m}^{-1}$, considering the threshold salinity of the crop (Ayers \& Westcot, 1999). The total productivity (PRTOT) showed an overall average of $59.61 \mathrm{tha}^{-1}$ and for commercial productivity (PRCOM) the average was $44.53 \mathrm{t} \mathrm{ha}^{-1}$.

The observed averages are in accordance with the values found by Araújo Neto et al. (2003) who found 41.0 to $63.2 \mathrm{t} \mathrm{ha}^{-1}$ for total productivity and 34.6 to $60.5 \mathrm{t} \mathrm{ha}^{-1}$ for commercial productivity when working with the productivity and quality of yellow melon genotypes in four environments in the western potiguar, RN, Brazil, which are types of melons that have higher yields than Cantaloupe types.

For commercial productivity, a value lower than the average obtained in the present study was verified by Medeiros et al. (2011) who obtained an average of $33.87 \mathrm{t} \mathrm{ha}^{-1}$ when they worked with the production and quality of Cantaloupe melon cultivated with water of different salinity levels. Also according to the authors, there was a $37.19 \%$ reduction in commercial fruit productivity between the lowest and highest salinity

Table 3. Summary of analysis of variance and means for total productivity (PRTOT) and commercial productivity (PRCOM) of melon

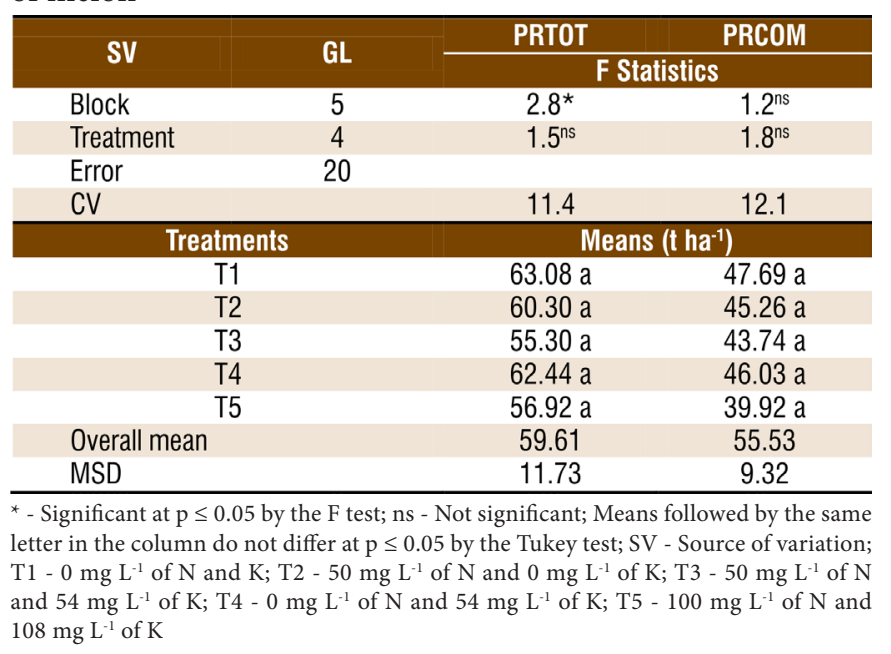

levels studied (electrical conductivity of irrigation water ranged from 0.6 to $4.3 \mathrm{dS} \mathrm{m}^{-1}$ ). Thus, the $\mathrm{T} 1$ treatment, as it has a lower concentration of salts in the irrigation water, is the most suitable.

Thus, it is likely that the contribution of the increase in the concentration of $\mathrm{N}$ and $\mathrm{K}$ in the soil solution to plants resulting from the treatments, was eliminated by the increase in the osmotic pressure of the soil due to the increase in the levels of these nutrients together with the other ions that go together with the fertilizers applied, considering that fertilizers are salts. Thus, it is essential to monitor the concentrations of nutrients in the soil, in addition to the total concentration of all ions in the soil solution, expressed in electrical conductivity of the soil solution, so that fertigations are performed as a complement to the needs of the crop, also considering the exchangeable ions, such as potassium.

\section{Conclusions}

1. The melon cultivated in soil with high $\mathrm{K}$ content and application of $18 \mathrm{~kg} \mathrm{ha}^{-1}$ of $\mathrm{N}$ in foundation did not increase production when fertigated with nitrogen and potassium.

2. The doses of $\mathrm{N}$ and $\mathrm{K}$ applied in fertigation altered the leaf concentration of $\mathrm{K}, \mathrm{Fe}$ and $\mathrm{B}$, but did not cause nutritional deficiency in the melon.

3. The application of fertilizers in increasing doses, in order to meet certain concentrations of potassium and nitrogen in the soil solution, contribute to the accumulation of salts in the soil.

\section{Literature Cited}

Allen, R. G.; Pereira, L. S.; Raes, D.; Smith, M. Evapotranspiración del cultivo: Guías para la determinación de los requerimentos de água de los cultivos. Rome: FAO, 2006. 298p.

Anjos, D. C. dos; Hernandez, F. F. F.; Costa, J. M. C. da; Caballero, S. S. U.; Moreira, V. O. G. Fertilidade do solo, crescimento e qualidade de frutos do mamoeiro Tainung sob fertirrigação com potássio. Revista Ciência Agronômica, v.46, p.774-785, 2015. https://doi. org/10.5935/1806-6690.20150065

Araújo Neto, S. E. de; Gurgel, F. de L.; Pedrosa, J. F.; Ferreira, R. L. F; Araújo, A. de P. Produtividade e qualidade de genótipos de melão-amarelo em quatro ambientes. Revista Brasileira de Fruticultura, v.25, p.104-107, 2003. https://doi.org/10.1590/ S0100-29452003000100030

Ayers, R, S.; Westcot, D. W. A qualidade da água na agricultura. 2 ed. Campina Grande: UFPB. 1999. 153p.

Callegari, A. R.; Sousa, M. M. G. de; Miranda, O. de N.; Góes, B. G. de; Silva, F. R. Á. da. Produtividade de frutos e teores de nutrientes no solo durante um cultivo de meloeiro. Revista Brasileira de Ciências Agrárias, v.7, p.24-36, 2012. https://doi.org/10.5039/ agraria.v7ila1146

Cantarella, H. Nitrogênio. In: Novais, R. F.; Alvarez V., V. H.; Barros, N. F.; Fontes, R. L. F.; Cantarutti, R. B.; Neves, J. C. L. Fertilidade do solo. Viçosa: SBCS, 2007. Cap.7, p.374-470.

Coelho, E. F.; Costa, F. da S.; Silva, A. C. P. da; Carvalho, G. C. Concentração de nitrato no perfil do solo fertirrigado com diferentes concentrações de fontes nitrogenadas. Revista Brasileira de Engenharia Agrícola e Ambiental, v.18, p.263-269, 2014. https://doi.org/10.1590/S1415-43662014000300004 
Cometti, N. N.; Furlani, P. R.; Ruiz, H. A.; Fernandes Filho, E. I. Soluções nutritivas: Formulação e aplicações. In: Fernandes, M. S. Nutrição mineral de plantas. Viçosa: SBCS, 2006. Cap.4, p.90-112.

Damasceno, A. P. A. B.; Medeiros, J. F. de; Medeiros, D. C. de; Melo, I. G. C.; Dantas, D. C da. Crescimento e marcha de absorção de nutrientes do melão Cantaloupe tipo "Harper" fertirrigado com doses de N e K. Revista Caatinga, v.25, p.137-146, 2012.

Dechen, A. R.; Nachtigall, G. R. Micronutrientes. In: Fernandes, M. S. Nutrição mineral de plantas. Viçosa: SBCS, 2006. Cap.13, p.328-352.

EMBRAPA - Empresa Brasileira de Pesquisa Agropecuária. Manual de análises química de solo, planta e fertilizantes. 2.ed. rev. ampl. Brasília: Embrapa Informações Tecnológicas, 2009. 627p.

EMBRAPA - Empresa Brasileira de Pesquisa Agropecuária. Manual de métodos de análises de solo. 3.ed. rev. ampl. Brasília, DF: Embrapa, 2017. 573p.

Gomes, E. R.; Broeito, F.; Queluz, J. G. T.; Bressan, D. F. Efeito da fertirrigação com potássio sobre o solo e produtividade do morangueiro. Irriga, v.esp., p.107-122, 2015. https://doi. org/10.15809/irriga.2015v1n1p107

Matos, A. T. de; Gariglio, H. A. de A.; Monaco, P. A. V. lo. Deslocamento miscível de cátions provenientes da vinhaça em colunas de solo. Revista Brasileira de Engenharia Agrícola e Ambiental, v.17, p.743-749, 2013. https://doi.org/10.1590/S141543662013000700008

Medeiros, D. C.; Medeiros, J. F.; Pereira, F. A. L.; Souza, R. O.; Souza, P. A. Produção e qualidade de melão Cantaloupe cultivado com água de diferentes níveis de salinidade. Revista Caatinga, v.24, p.92-98, 2011.

Meurer, E. J. Potássio. In: Fernandes, M. S. Nutrição mineral de plantas. Viçosa: SBCS, 2006. Cap.11, p.282-295.

Miranda, N. de O.; Oliveira, T. S.; Medeiros, J. F.; Levien, S. L. A. Causas da variação em produtividade e qualidade do melão em um Latossolo Vermelho-Amarelo fertirrigado. Ciência Rural, v.36, p.487-493, 2006. https://doi.org/10.1590/S010384782006000200019
Oliveira, F. de A.; Duarte, S. N.; Medeiros, J. F. de; Dias, N. da S.; Oliveira, M. K. T.; Silva, R. C. P.; Lima, K. S. Nutrição mineral do pimentão submetido a diferentes manejos de fertirrigação. Horticultura Brasileira v.33, p.216-223, 2015. https://doi. org/10.1590/S0102-053620150000200013

Oliveira, F. de A.; Duarte, S. N.; Medeiros, J. F. de; Dias, N. da S.; Silva, R. C. P. da; Lima, C. J. G. de S. Manejo da fertirrigação e doses de $\mathrm{N}$ e K no cultivo de pimentão em ambiente protegido. Revista Brasileira de Engenharia Agrícola e Ambiental, v.17, p.1152-1159, 2013. https://doi.org/10.1590/S1415-43662013001100004

Oliveira, S. F. de; Oliveira, S. F. de; Araujo, L. J.; Rocha, C. R.; Rocha, C. H. G. Partição e acumulação de nutrientes no meloeiro amarelo fertirrigado em condições semiáridas. Irriga, v.21, p.545-560, 2016. https://doi.org/10.15809/irriga.2016v21n3p545-560

Pereira Filho, V. J.; Bezerra, L. M. F.; Silva, A. R. A. da; Sousa, de M. C. C. de; Castro, M. J. de. Frequência de irrigação e aplicação de $\mathrm{N}$ em meloeiro irrigado por gotejamento nas condições semiáridas do Nordeste. Científica, v.42, p.11-22, 2014. https:// doi.org/10.15361/1984-5529.2014v42n1p11-22

Santos, A. P. G.; Viana, T. V. A.; Sousa, G. G. de; Gomes-do-Ó, L. M.; Azevedo, B. M.; Santos, A. M. Produtividade e qualidade de frutos do meloeiro em função de tipos e doses de biofertilizantes. Horticultura Brasileira, v.32, p.409-416, 2014. https://doi. org/10.1590/S0102-053620140000400007

Silva, A. G. da. Caracterização e aptidão agrícola de solos representativos do agropólo Mossoró-Assu. Mossoró: UFERSA, 2018. 74p. Dissertação Mestrado.

Silva, M. de C.; Silva, T. J. A. da; Bomfim-Silva, E. M.; Farias, L. do N. Características produtivas e qualitativas de melão rendilhado adubado com nitrogênio e potássio. Revista Brasileira de Engenharia Agrícola e Ambiental, v.18, p.581-587, 2014. https:// doi.org/10.1590/S1415-43662014000600003

Silva Júnior, M. J. da; Viana, P. C.; Medeiros, J. F. de; Lima, J. G. A.; Targino, A. J. de O. Watermelon fertigation with electrical conductivity and $\mathrm{pH}$ monitoring in the soil solution. Engenharia Agrícola v.36, p.622-6, 2016. https://doi.org/10.1590/1809-4430Eng.Agric.v36n4p622-630/2016 